bezpieczeństwa Azji Południowej trudno uznać za stabilny. Na szczególną uwagę zasługują również dwa rozdziały poświęcone tzw. podmiotom nieterytorialnym jako mocarstwom. W oryginalnym ujęciu Ryszarda Zięby, polityka zagraniczna prowadzona przez Unię Europejską może być postrzegana przez pryzmat: ekonomii jako „wspólnotowa polityka zagraniczna” (s. 217), polityki jako „Wspólna Polityka Zagraniczna i Bezpieczeństwa” (s. 223) oraz w kontekście polityczno-militarnym jako „Wspólna Polityka Bezpieczeństwa i Obrony” (s. 229). W równie ciekawym tekście Katarzyna Marzęda-Młynarska zastanawia się nad znaczeniem korporacji międzynarodowych w polityce międzynarodowej, które określa mianem „nowego fenomenu”. Z poglądem tym można się zgodzić jedynie czéściowo bowiem, jak zauważa sama Autorka, „ich [korporacji międzynarodowych - M.R.] »debiut« w badaniach na gruncie stosunków międzynarodowych przypadł na lata 70 . XX wieku" (s. 236). Z kolei niewątpliwym atutem tej części pracy jest zaprezentowanie wielowymiarowego wpływu korporacji transnarodowych na politykę międzynarodową (s. 245-256).

W części III i IV niniejszego działa podjęto wysiłek zanalizowania polityki zagranicznej państw średniego rzędu oraz państw małych i minipaństw. Na szczególną uwagę zasługuje ukazanie Polski, również w kontekście polityki Partnerstwa Wschodniego, zawieszonego między prometeizmem a mesjanizmem (283-285), Turcji stojącej „W rozkroku” między Wschodem a Zachodem i Izraela. Szkoda jednak, że w tej grupie państw nie znalazł się Iran, państwo niewątpliwie znaczące, uznawane za przeciwwagę w regionie dla ambicji Izraela. W ostatnim rozdziale scharakteryzowano politykę zagraniczną państw małych i minipaństw. Skupienie się na państwach różnorodnych pod niemal każdym względem, jak: Czechy, Gruzja, Senegal czy Liechtenstein należy uznać za zabieg właściwy, pozwalający czytelnikowi na wyrobienie perspektywy porównawczej.

Dzieło pod redakcją T. Łoś-Nowak prezentuje się jako praca staranna. Została zaopatrzona we wprowadzenie, część merytoryczną składającą się z czterech części, podsumowanie, rozległą bibliografię oraz indeks ułatwiający pracę z tekstem. Warto też zaznaczyć, że poszczególne rozdziały kończą się podsumowaniami, co systematyzuje wiedzę i pozwala na dokonanie koniecznych uogólnień.

Należy też zauważyć, że dzieło Teresy Łoś-Nowak wyróżnia się występowaniem tzw. novum. Na nowatorski charakter książki wpływa nie tylko jej przemyślana struktura, ale także umiejętne połączenie teorii i ontologii oraz wyjście poza tradycyjne postrzeganie polityki zagranicznej możliwe dzięki podkreśleniu znaczenia polityki międzynarodowej. Doceniając walory prezentowanej książki, należy zauważyć, że stanowi ona kolejny etap budowy polskiej szkoły myślenia o stosunkach międzynarodowych. Dzięki uwzględnieniu szerokiego spektrum zagadnień można ją uznać za lekturę obowiązkową dla studentów, naukowców oraz praktyków zajmujących się lub zainteresowanych polityką zagraniczną.

MAREK REWIZORSKI

\title{
Janusz Józef Węc, Traktat lizboński. Polityczne aspekty reformy ustrojowej Unii Europejskiej w latach 2007-2009, Księgarnia Aka- demicka, Kraków 2011.
}

Integracja europejska, to bardzo złożony proces, trwający w formie jaką dziś znamy od pierwszych lat po II wojnie światowej. Począwszy od różnych powojennych planów i koncepcji integracyjnych tworzonych przez europejskie elity społeczne i polityczne, poprzez powstanie Wspólnot Europejskich aż po utworzenie Unii Europejskiej, proces ten nigdy nie był statyczny, a wręcz przeciwnie - ulegał ciagłym modyfikacjom i kierował się własną wewnętrzną dynamiką. 
Traktat o Unii Europejskiej uzgodniony 10 grudnia 1991 r. pomiędzy rządami państw członkowskich, był ważnym etapem w tworzeniu nowej i bardziej zaawansowanej struktury europejskiej. Jednak mając na uwadze przeobrażenia, jakie dokonywały się na kontynencie europejskim, i dynamikę samego procesu integracji, państwa członkowskie, na mocy art. N TUE (w numeracji nieskonsolildowanej), pozostawiły możliwość wprowadzania w przyszłości zmian w tym traktacie uprzednio uzgodnionych w konferencji międzyrządowej (IGC). Tak też się stało, zmiany zostały wprowadzone na mocy Traktatu amsterdamskiego z $2.10 .1997 \mathrm{r}$. (m.in. wprowadzenie zasady ściślejszej współpracy, rozszerzenie stosowania procedury współdecydowania, skonsolidowanie numeracji artykułów w traktatach) oraz Traktatem z Nicei, podpisanym 26 lutego 2001 r., którego główne postanowienia dotyczyły zmian instytucjonalnych przygotowujących Unię Europejską do planowanego wschodniego rozszerzenia.

Monografia naukowa autorstwa Janusza Węca zatytułowana Traktat lizboński. Polityczne aspekty reformy ustrojowej Unii Europejskiej w latach 2007-2009 (Wyd. Księgarnia Akademicka, Kraków 2011, ss. 348) ukazuje nam Unię Europejską w okresie ostatniej, czyli lizbońskiej rewizji traktatowej.

Jak napisał Autor, intencją książki była „rekonstrukcja zdarzeń, prowadzących do zwołania konferencji międzyrządowej w 2007 r., odtworzenie procesu negocjacji dyplomatycznych nad nowym traktatem rewizyjnym podczas obrad tejże konferencji, przedstawienie jej rezultatów, analiza najważniejszych zmian ustrojowych skodyfikowanych w Traktacie lizbońskim, a także omówienie procesu jego ratyfikacji"1.

Książka, nie licząc uwag wstępnych Autora i zakończenia, składa się z pięciu rozdziałów, zakończenia, bibliografii oraz aneksów w formie wykazu skrótów, tabel, wykresów czy indeksu osób. Recenzowany tekst zawiera więc pełny aparat naukowy.

Rozdziały można pogrupować na dwie części. Pierwsza z nich (rozdziały I i II) omawia to, co działo się przed podpisaniem Traktatu lizbońskiego, a druga (rozdziały III, IV i V) dotyczy już samych zmian wprowadzonych przez traktat i przebieg procesu jego ratyfikacji. W rozdziale pierwszym Ewolucja reformy ustrojowej Unii Europejskiej Autor analizuje najważniejsze zmiany instytucjonalne wprowadzone przez traktaty amsterdamski i nicejski, a także bardzo interesującą i ważną dla dalszych rozważań kwestię traktatu konstytucyjnego. Czytelnik może dowiedzieć sięjak wyglądały etapy prac nad traktatem konstytucyjnym, jaki był cel jego tworzenia, jak doszło do podpisania i dlaczego projekt ten poniósł fiasko. W sposób syntetyczny Autor wykorzystując swoje wcześniejsze badania ${ }^{2}$ przedstawia najważniejsze zmiany, jakie miał wprowadzić traktat konstytucyjny, będący w zamierzeniach legislatorów kompleksową reformą UE.

Rozdział II zatytułowany Konferencja międzyrzqdowa w $2007 \mathrm{r}$. poświęcony został w całości etapowi przygotowywania nowego traktatu rewizyjnego, który po niepowodzeniu traktatu konstytucyjnego, miałby doprowadzić do reformy ustrojowej Unii Europejskiej, tak aby była ona gotowa stawić czoła nowym wyzwaniom, zarówno na arenie wewnętrznej, jak i w otoczeniu międzynarodowym. Dużą rolę w tworzeniu nowego traktatu Autor przypisuje Niemcom, co jest zrozumiałe, gdyż to Niemcy byli weześniej zwolennikami traktatu konstytucyjnego, optowali za jego ratyfikacją. Ówczesny minister spraw zagranicznych J. Fischer przemawiając w Bundestagu 3 lipca 2003 r. stwierdził, że proponowana konstytucja jest następstwem rozszerzenia UE. Według niego, ,,rozszerzenie jest historycznie nieuniknione, ale wymaga też 'reorganizacji europejskich instytucji' po to, by zjednoczona Europa była zdolna do działania, ponieważ większa, tj. licząca 450 milionów obywatelek i obywateli oraz 25 i być może więcej państw członkowskich

J. J. Węc, Traktat lizboński. Polityczne aspekty reformy ustrojowej Unii Europejskiej w latach 2007-2009, Kraków 2011, s. 11.

2 J. J. Węc, Spór o ksztalt instytucjonalny Wspólnot Europejskich i Unii Europejskiej 1950-2005. Między idea ponadnarodowości a wspótpraca międzyrzadowa. Analiza politologiczna, Kraków 2006. 
czyni UE bardziej nieprzejrzystą i coraz mniej zrozumiałą" ". Zjednoczona Europa musi działać demokratycznie i przejrzyście. Dlatego ważne było umieszczenie w konstytucji Karty Praw Podstawowych, a także potwierdzenie zasady subsydiarności. Aby uspokoić tych, którzy obawiali się zredukowania roli państw narodowych i ich organów Fischer zapewnił, że rola narodowych parlamentów jako strażników [suwerenności - M.Ż.] zostanie uroczyście zapisana. Stwierdził, że Niemcy mają doświadczenie nabyte podczas procesu zjednoczenia więc mogą wykorzystać je także na ogólnoeuropejskiej płaszczyźnie ${ }^{4}$. Mimo referendalnego odrzucenia traktatu konstytucyjnego przez Francuzów i Holendrów, politycy niemieccy namawiali do nieprzekreślania idei konstytucyjnej oraz opracowania traktatu w zmienionej formie, takiej by była do przyjęcia przez wszystkie państwa członkowskie. Okazja nadarzyła się, gdy Niemcy objęły prezydencję w Unii Europejskiej w pierwszej połowie 2007 r. Na pierwszym szczycie UE podczas tej prezydencji, w dniach 8-9 marca 2007 r., przyjęto tzw. Deklarację Berlińską -która podkreślała wartości łączące UE 27 krajów i wyznaczała zadania na przyszłość. Ułatwiło to osiągnięcie porozumienia 23 czerwea na unijnym szczycie w Brukseli, gdzie przyjęto projekt przyszłego traktatu w postaci tzw. mandatu mającego stanowić podstawę i ramy dla prac konferencji międzyrządowej, która z kolei miała przygotować ostateczną wersję traktatu. Dzięki prezydencji niemieckiej można było rozpocząć prace nad ostatecznym kształtem traktatu, który podpisano w Lizbonie 13 grudnia 2007 r., już podczas prezydencji portugalskiej. Czytelnik może prześledzić tok prac i negocjacji nad nowym traktatem, metodologię działań rządu niemieckiego, który był zdeterminowany, aby odnieść sukces. Przejrzyście prowadzona przez Autora narracja pozwala zobaczyć sposoby dochodzenia do kompromisu i metody podejmowania decyzji na szczytach unijnych.

W dalszej części książki omawiane są zmiany wprowadzone przez Traktat lizboński. Autor dokonał tu ciekawego zabiegu, dzieląc zmiany traktatowe na horyzontalne i sektorowe. Rozdział III Zmiany horyzontalne jest najobszerniejszym i prezentuje to, co traktat wnosi nowego do ustroju UE. Na pierwszym miejscu wyeksponowano ustanowienie nowego statusu prawnomiędzynarodowego Unii, wskazując na to, że Unia Europejska po raz pierwszy uzyskała osobowość prawną, stając się jednolitą organizacją międzynarodową, ale, co Autor podkreśla, celem Unii nie jest przekształcenie jej w organizację międzynarodową jednego narodu europejskiego, lecz tylko „głębsza integracja państwowo zorganizowanych narodów”. To pozwalało złagodzić obawy niektórych narodów, przeciwnych tworzeniu federacji europejskiej w postaci Stanów Zjednoczonych Europy wzorowanych na Stanach Zjednoczonych Ameryki Północnej. Przedstawiona została inicjatywa obywatelska, jako nowa ,instytucja” wprowadzona przez Traktat lizboński, której pierwotną ideą było i wciąż pozostaje zmniejszanie deficytu demokracji w UE. W Efekcie tej regulacji, pojawiła się możliwość złożenia podpisanej przez milion osób petycji do Komisji Europejskiej, by ta wystąpiła z projektem nowego aktu prawnego. W omawianym rozdziale zostały przedstawione takie zagadnienia jak: podział kompetencji pomiędzy Unią a państwami członkowskimi, usystematyzowanie katalogu aktów prawnych i nowych procedur decyzyjnych, czy też szczegółowa reforma systemu instytucjonalnego Unii, z podziałem na instytucje. Ponadto możemy się dowiedzieć, na czym będzie polegać zasada podwójnej większości (od 2014 r. decyzje Rady będą wymagały poparcia 55\% państw członkowskich i nie mniej niż $65 \%$ ludności UE). Autor nie pominął przy tym analizy nowej, zwiększonej roli parlamentów narodowych w procesie legislacyjnym. Będą one mogły kontrolować projekty aktów prawnych UE pod kątem przekroczenia kompetencji Unii w sprawach, które powinny być rozstrzygnięte na pozio-

3 Rede von Bundesaußenminister Fischer zur Erweiterung der EU, gehalten vor dem Deutschen Bundestag am 3.07.2003 in Berlin (Auszug), www.auswartiges-amt.de/diplo/de/Infoservice/Presse/Reden/Archiv.

4 Ibidem. 
mie krajowym, regionalnym lub lokalnym. Niewątpliwym walorem omawianego rozdziału jest usystematyzowanie przez Autora zmian dokonanych w traktacie. Osoby zainteresowane problematyką integracji europejskiej mogą w łatwy sposób zdobyć ważne dla nich informacje.

W rozdziale IV zatytułowanym Zmiany sektorowe poruszono reformy i zmiany dwóch obszarów działań: wspólnej polityki zagranicznej i bezpieczeństwa oraz przestrzeni wolności, bezpieczeństwa i sprawiedliwości. Zabrakło być może w tym rozdziale odniesienia się do innych polityk sektorowych np. spójności, socjalnej, gospodarczej, ale o ile rozumiem intencje Autora, założył on zbadanie najistotniejszych zmian, a te zaszły głównie w dawnym II i III filarze Unii Europejskiej.

Ostatni, V rozdział pt. Ratyfikacja traktatu lizbońskiego, jest najkrótszym w omawianej pracy. Mimo to, dotyczy on o bardzo ważnej sprawy ratyfikacji traktatu. Biorąc pod uwagę to, co stało się z traktatem konstytucyjnym, ratyfikacja nie była wcale z góry przesądzona. Cały czas pozostawały obawy, że społeczeństwa europejskie oraz politycy niechętni Traktatowi lizbońskiemu, będą uznawali go za próbę wprowadzenia w życie upadłego traktatu konstytucyjnego „tylnymi drzwiami”. Autor podzielił proces ratyfikacji na dwie fazy, w pierwszej fazie umieszczając ratyfikacje na poziomie narodowym przebiegające dość szybko i bez większych trudności (ta faza zakończyła się 20 listopada 2008 r. ratyfikacją przez Szwecję) a w drugiej fazie ratyfikacje, które napotkały trudności, w takich państwach jak: Czechy, Irlandia, Niemcy i Polska. Każdy z tych przypadków został poddany refleksji naukowej, przedstawione zostały motywy i działania polityków mających wątpliwości, czytelnik może prześledzić jak trudny był proces ratyfikacji w tej fazie. Niemniej zakończył się on powodzeniem, a ostatnim państwem, które ratyfikowało Traktat lizboński były Czechy (13 listopada 2009 r.). W rezultacie traktat wszedł w życie 1 grudnia $2009 \mathrm{r}$.

Monografia J. J. Węca dzięki rzetelnej rekonstrukcji procesów politycznych, legislacyjnych i dyplomatycznych wewnątrz UE, które towarzyszyły procesowi kreacji Traktatu lizbońskiego, staje się istotnym elementem aktualizującym polskie piśmiennictwo naukowe, a tym samym podstawowym opracowaniem wzbogacającym stan badan w studiach europejskich.

Narracja Autora oparta jest o dość przejrzyste kryterium chronologiczno-merytoryczne. Pozwala to czytelnikowi na zapoznanie się z procesem powstawania Traktatu lizbońskiego zgodnie z osią czasu, dzięki czemu dowiaduje się, jakie były następstwa decyzji politycznych odnośnie traktatu, dlaczego jest skonstruowany w specyficzny sposób i w jaki sposób doszło do jego ratyfikowania.

Książka J. J. Węca została napisana na podstawie szerokiej bazy źródłowej. Autor wykazał się znajomością bogatej literatury europeistycznej oraz niemcoznawczej. Dużo miejsca w bibliografii zajmują dokumenty w językach polskim, niemieckim i angielskim co świadczy o bogatej podstawie źródłowej recenzowanej książki. Ponad 110 monografii, wielka ilość ekspertyz, artykułów zarówno z prac zbiorowych, jak i czasopism (wykorzystane zostały artykuły z niemieckich wydawnictw takich jak „Integration” czy „Bulletin des Presse- und Informationsamtes der Bundesregierung”), pozwala stwierdzić, iż książka powstała przy wykorzystaniu możliwie największej ilości dostępnych materiałów.

Ciekawym i pomocnym w lekturze pomysłem Autora są tabele i wykresy, zwłaszcza te ostatnie. Dzięki temu Autor mógł przedstawić najważniejsze zagadnienia poruszane w książce w przejrzysty sposób, a czytelnik może łatwiej przyswoić mechanizmy i procesy występujące w procesie integracji europejskiej - to niewątpliwa zaleta publikacji.

Opracowanie J. J. Węca jako szczegółowe i specjalistyczne studium poświęcone Traktatowi lizbońskiemu zasługuje na uwagę i warte jest polecenia nie tylko politologom czy europeistom, ale także wszystkim tym, którzy interesują się problematyką europejską i stosunkami międzynarodowymi. 